\title{
Etika Aparatur Pemerintah Daerah Dalam Pelayanan Adminsitrasi Kependudukan Masa Pandemi Covid-19 Di Kantor Dinas Kependudukan Dan Pencatatan Sipil Kabupaten Mempawah
}

\author{
Bima Sujendra $^{1}$, Nahot Tua Parlindungan Sihaloho ${ }^{2}$ \\ 1,2Program Studi Ilmu Pemerintahan, Fakultas Ilmu Sosial dan Ilmu Politik, \\ Universitas Tanjungpura, Kota Pontianak, Provinsi Kalimantan Barat \\ Corresponding Author: nahotsihaloho@fisip.untan.ac.id
}

Keyword: Government Ethics; Civil Servant; Public Service; Covid-19;

\begin{abstract}
This study conducted a study of the Ethics of Local Government Apparatuses in Population Administration Services at the Mempawah Regency Population and Civil Registration Office during the Covid 19 Period. The formulation of the problem in this study is how the ethics of local government officials in the service of making Electronic ID cards at the Population and Registration Office Civil Society of Mempawah Regency during the Covid 19 period. The research method used by researchers is a qualitative approach, with data collection techniques through observation, interview documentation. The theory used to analyze in this research is the Indicators of State Administration Ethics according to Surjadi, which consists of Honesty, Fairness, Obedience to Rules, Responsibility, and Fairness. The results showed that the Honesty aspect was good; this was seen from the absence of illegal levies and did not cover up the complaints obtained from the community related to being unsatisfactory in providing services. The justice aspect is not good because there is still discrimination in providing services to the community. Aspects of Obeying the Rules are still not good; this can be seen from the apparatus that does not obey the regulations, namely the discipline of working hours. Aspects of Fairness and Property are still not good, and this can be seen from the lack of friendliness of the apparatus in serving the public who ask questions related to information on making and taking Electronic ID cards. The advice given by the researcher is that the Disdukcapil of Mempawah Regency is expected to increase awareness to be ethical in providing services by making SOPs related to being ethical in providing services during the covid 19 periods.
\end{abstract}

\section{PENDAHULUAN}

Pelayanan merupakan salah satu tugas aparatur pemerintahan selaku penyelenggara pelayanan publik yang ditujukan untuk membantu masyarakat dalam memenuhi kebutuhannya. Berdasarkan Undang-Undang Nomor 25 Tahun 2009 tentang Pelayanan Publik ditetapkan bahwa pelayanan publik adalah kegiatan atau rangkaian kegiatan yang berkaitan dengan pemenuhan kebutuhan pelayanan sesuai dengan ketentuan hukum bagi seluruh warga negara dan penghuni properti, pelayanan administrasi. atau layanan yang disediakan oleh penyedia layanan publik. Aparatur pemerintah dalam memberikan pelayanan publik kepada masyarakat dituntut untuk melayani dengan cepat, tepat, murah, aman, berkeadilan, dan akuntabel. Organisasi pemerintahan pada hakikatnya merupakan bagian atau berhubungan dengan masyarakat, yang berfungsi sebagai pemberi layanan secara langsung kepada masyarakat. Aparatur Pemerintah selaku penyedia pelayanan publik pun terus dituntut untuk bertanggungjaawab dan berusaha memberikan pelayanan yang baik kepada masyarakat untuk meningkatkan kualitas pelayanan publik. 
Aparat pemerintah yang bertugas memberikan pelayanan kepada masyarakat harus berorientasi kepada kepentingan masyarakat berdasarkan asas transparansi dan akuntabilitas. Dengan demikian pelayanan yang berkualitas akan dapat tercapai sehingga membuat tingkat kepercayaan masyarakat terhadap pemerintah menjadi tinggi. Salah satu faktor yang menyebabkan kurang baiknya pelayanan publik pada saat ini adalah masih kurangnya etika sumber daya manusia aparatur pemerintah dalam memberikan pelayanan kepada masyarakat. Hal ini dapat dilihat dari banyaknya keluhan masyarakat yang berkaitan dengan perilaku dan tindakan aparatur pemerintah yang dianggap kurang responsif dengan kebutuhan masyarakat, dan juga sikap yang kurang ramah dalam pelayanan. Bagi Aparatur pemerintah, nilai-nilai etik yang harus diaktualisasikan dalam sikap/perilakunya terdapat dalam Undang-Undang Nomor 5 Tahun 2014 tentang Aparatur Sipil Negara.

Pasal 4 undang-undang tersebut terdapat nilai-nilai dasar yang teridir dari Profesional, Tidak Berpihak, Memelihara Dan Menjunjung Tinggi Standar Etika Yang Luhur, Dapat Mempertanggungjawabkan Tindakan Dan Kinerjanya Kepada Publik, Memberikan Layanan Kepada Publik Secara Jujur, Tanggap, Cepat, Tepat, Akurat, Serta Santun, Nilai-nilai dasar tersebut diarahkan dan dijaga dengan norma etik yang berupa kode etik Pegawai ASN (Aparatur Sipil Negara) yang terdapat dalam pasal 5 ayat (2) agar dapat bersikap/berperilaku etis seperti dapat melaksanakan tugasnya dengan jujur, bertanggungjawab, dan berintegritas tinggi dan sesuai dengan ketentuan peraturan perundang-undangan, melayani dengan sikap hormat, sopan, dan tanpa tekanan, memegang teguh nilai dasar ASN (Aparatur Sipil Negara), serta melaksanakan ketentuan peraturan perundang-undangan mengenai disiplin Pegawai ASN.

Dalam meningkatkan kualitas pelayanan administrasi kependudukan pemerintah mengeluarkan Peraturan Menteri Dalam Negeri Republik Indonesia Nomor 19 Tahun 2018 Tentang Peningkatan Kualitas Layanan Administrasi Kependudukan. Pada pasal 3 ayat (1) dan (2) dijelaskan sebagai berikut bahwa (1) Dokumen kependudukan yang ditingkatkan kualitas pelayanannya paling sedikit KK, KTP-el, Akta Kelahiran, Akta Perkawinan, Akta Kematian; dan Surat Keterangan Pindah. Penerbitan dokumen kependudukan sebagaimana dimaksud pada ayat (1) diselesaikan dalam waktu 1 (satu) jam dan paling lama 24 (dua puluh empat) jam sejak persyaratan dinyatakan lengkap oleh petugas pelayanan pada Dinas Kependudukan dan Pencatatan Sipil Kabupaten/Kota. Di dalam Peraturan Menteri Dalam Negeri Republik Indonesia Nomor 19 Tahun 2018 Tentang Peningkatan Kualitas Layanan Administrasi Kependudukan, Dinas Kependudukan Dan Catatan Sipil memiliki tugas pokok dan fungsi:

1. Perumusan dan pelaksanaan kebijakan teknis di bidang pendaftaran penduduk, pencatatan sipil, pengelolaan informasi administrasi kependudukan, kerja sama, pemanfaatan data dan dokumen kependudukan serta inovasi pelayanan administrasi kependudukan;

2. Pelaksanan evaluasi dan pelaporan serta administrasi di bidang pendaftaran penduduk, pencatatan sipil, pengelolaan informasi administrasi kependudukan, kerja sama, pemanfaatan data dan dokumen kependudukan serta inovasi pelayanan administrasi kependudukan;

3. Pelaksanaan tugas lain yang diberikan oleh bupati sesuai dengan tugas dan fungsinya; dan

4. Pelaksanaan tugas pembantuan dari pemerintah dan pemerintah provinsi yang diberikan kepada kabupaten sesuai dengan tugas dan fungsinya.

Dinas Kependudukan dan Pencatatan Sipil Kabupaten Mempawah merupakan salah satu instansi pemerintah yang wajib memberikan pelayanan yang baik kepada masyarakatnya. Bentuk pelayanan administrasi kependudukan yang diberikan Dinas 
Kependudukan dan Pencatatan Sipil Kabupaten Mempawah adalah berupa pembuatan Kartu Keluarga (KK), Kartu Tanda Penduduk (KTP), Akta Kelahiran, Perkawinan, dan Kematian. Semenjak munculnya virus corona (Covid 19) dalam pelayanan administrasi kependudukan khususnya dalam pembuatan KTP Elektronik pemerintah Kabupaten Mempawah mendapat keluhan dari masyarakat dalam memberikan pelayanan. Berdasarkan hasil Survei peneliti pada Dinas Kependudukan dan Pencatatan Sipil Kabupaten Mempawah pada masa Covid 19 ini, terlihat lambatnya pembuatan KTP Elektorinik. Masyarakat mengeluhkan pelayanan pembuatan KTP Elektorinik yang dirasa lambat pada saat covid 19 ini, padahal masyarakat sangat membutuhkan KTP untuk melengkapi dokumen-dokumen yang berkaitan dengan bantuan pemerintah yang akan disalurkan pada masa covid 19. Masyarakat mengeluhkan lamanya pelayanan KTP Elektornik tersebut, dimana semenjak adanya virus corona pelayanan hanya melayani maksimal 30 orang perhari.

Peneliti melihat penyebab lambatnya pelayanan yang diberikan disebabkan oleh diterapkannya protocol kesehatan dan juga jam operasional baru. Selain itu keterbatasan jumlah aparatur dan kurang disiplinnya aparatur yang ada Di Disdukcapil Kabupaten Mempawah dalam bekerja. Ada pegawai yang datang bekerja tidak tepat waktu, seperti datang bekerja di atas jam 09:00 WIB bahkan ada yang datang bekerja di atas jam 10:00 WIB, padahal jam kerja pelayanan pada masa Covid 19 Di Kantor Dinas Dukcapil Kabupaten Mempawah dimulai dari jam 09:00 WIB sampai dengan jam 16.00 WIB. Hal ini tentu berdampak pada melambatnya pelayanan yang diberikan mengingat banyaknya masyarakat yang harus menunggu dan mengantri untuk mendapatkan pelayanan.

Salah satu warga dari Desa Sungai Kunyit Laut yang mengeluhkan, susahnya mau membuat KTP Elektronik yang sudah satu minggu lebih namun tak kunjung jadi. Bliau menjelaskan berdasarkan informasi dari pihak Dinas Kependudukan Dan Pencatatan Sipil Kabupaten Mempawah sudah bisa di ambil sekitar tiga sampai dengan tujuh hari, namun pada waktu yang sudah ditentukan KTP Elektronik tersebut juga tak kunjung jadi. Bliau mengungkapkan bahwa dirinya telah sebanyak tiga kali bolak balik ke Kantor Dinas Kependudukan dan Pencatatan Sipil Kabupaten Mempawah untuk menanyakan. Selain itu bliau juga mengungkapkan sikap pegawai yang tidak ramah kepadanya saat ditanya kapan untuk bisa mengambil KTP Elektroniknya, Pegawai tersebut menjawab dengan intonasi tinggi dan mimik wajah yang tidak mengenakkan.

Pelayanan yang berkualitas perlu didukung dengan sikap dan perilaku yang baik dari aparat pemerintah pemberi layanan. Untuk itu dalam memberikan sebuah pelayanan aparat pemerintah memerlukan etika sebagai dasar dan pedoman dalam bertindak. Etika pemerintahan diperuntukan bagi para aparatrur pemerintah yang dituntut untuk mematuhi nilai dan moral yang berlaku sesuai dengan tugas dan tanggungjawabnya. Berdasarkan latar belakang yang telah di paparkan oleh peneliti diatas, maka peneliti tertarik untuk meneliti Etika Aparatur Pemerintah Daerah Dalam Pelayanan Adminsitrasi Kependudukan Di Kantor Dinas Kependudukan Dan Pencatatan Sipil Kabupaten Mempawah.

\section{METODE PENELITIAN}

Penelitian ini menggunakan pendekatan penelitian kualitatif dan Jenis penelitian yang digunakan adalah penelitian deskriptif. Lokasi penelitian ini adalah Di Dinas Kependudukan dan Pencatatan Sipil Kabupaten Mempawah. Alasan memilih Dinas Kependudukan dan Pencatatan Sipil Kabupaten Mempawah adalah adanya keluhan masyarakat setempat terkait dengan sikap aparatur yang kurang ramah dan sopan dalam memberikan pelayanan kepada masyarakat dalam pembuatan KTP Elektronik pada masa covid 19. Informan dalam penelitian ini adalah Kepala Dinas Disdukcapil Kabupaten 
Mempawah, Kepala Bagian Pendaftaran Penduduk (Dafduk) Disdukcapil Kabupaten Mempawah, 2 (dua) Staf/pegawai yang bekerja pada bidang pelayanan penduduk Disdukcapil Kabupaten Mempawah, 2 (orang) Security Disdukcapil Kabupaten Mempawah dan 5 (lima) masyarakat yang menerima pelayanan.

\section{HASIL DAN PEMBAHASAN Kejujuran}

Kejujuran mengacu pada aspek karakter, moralitas dan mewakili sifat positif dan berbudi luhur seperti integritas, kejujuran dan keterbukaan, termasuk keterbukaan perilaku, dan berjalan seiring dengan tidak adanya kebohongan, kecurangan, perselingkuhan. Kejujuran juga berarti untuk dapat dipercaya, adil, tulus, dan setia. Kejujuran merupakan keiklasan pegawai untuk mengerjakan setiap tugas yang menjadi tanggung jawabnya dan tidak melakukan penyimpangan di dalam pelaksanaannya (Kumorotomo, 2018, 407). Maka kejujuran seorang aparatur dapat dilihat dari ketulusannya saat melaksanakan tugas dalam memberikan pelayanan kepada msayarakat yang sesuai dengan standar pelayanan, tepat, dan benar tanpa ada penyimpangan. Untuk itu penting bagi aparatur mengetahui dan memahami etika dalam pelayanan public terkait dengan kejujuran ini, karena kejujuran merupakan bagian dari etika aparatur pemerintah dalam memberikan pelayanan.

Aparatur Sipil Negara Dinas Kependudukan dan Pencatatan Sipil Kabupaten Mempawah dalam bekerja sudah baik dan sesuai dengan tupoksi masing-masing, tidak ada penyalahgunaan wewenang pada pelaksanaan tugas-tugasnya. Namun terkait dengan durasi waktu dan kebijakan gratis didalam pembuatan KTP yang katanya sudah ditempel didepan, tidak ditemukan, sedangkan yang ditemukan hanya persyaratan terkait dengan pelayanan administrasi kependudukan Di Dinas Kependudukan dan Pencatatan Sipil Kabupaten Mempawah yang di tempel di papan informasi. Selain itu juga, terkait dengan transparansi seperti yang diungkapkan oleh kepala dinas masih belum transparansi karena informasi yang diberikan oleh aparat kepada masyarakat belum jelas dan kurangnya keterbukaan aparatur terhadap akses data mengenai pelayanan yang ada di kantor. Salah satu bentuknya adalah ketika diminta data, hanya data yang sudah dikonsolidasikan yang diperbolehkan untuk dilihat atau diketeahui, yaitu sudah dalam bentuk laporan tahunan, bukan data pelayanan seperti rekap per bulan atau persemester.

Adanya ketidak sesuain informasi yang di dapatkan dari pihak masyarakat dengan pihak Dinas Kependudukan dan Pencatatan Sipil Kabupaten Mempawah. Dari pengamatan dilapangan, memang terdapat beberapa orang yang masuk untuk tanpa memiliki nomor antrian dan juga tidak menemukan informasi terkain dengan perubahan jam operasional di papan informasi Dinas Kependudukan dan Pencatatan Sipil Kabupaten Mempawah. Informasi tersebut ternyata di tempelkan di pintu kantor, dimana informasi tersebut tidak terlihat pada saat pintu dibuka. Aparatur dalam bekerja sudah cukup baik, namun dalam pelaksanaan pelayanan pembuatan KTP Elektronik memang tidak semua masyarakat puas dengan pelayanan yang diberikan. Beberapa masyarakat ada yang tidak puas terhadap sikap yang ditunjukan oleh aparatur, terutama berkaitan dengan sikap yang kurang ramah saat memberikan pelayanan.

Kepala Dinas dan Kabid Dafduk pada Disdukcapil Kabupaten Mempawah terkait sikap perilaku aparatur mengakui bahwa memang ada keluhan terkait sikap yang kurang ramah dari aparaturnya dalam pelayanan. Hal ini disebabkan oleh minimnya penerapan aparatur terhadap etika pelayanan publik yang dikarenakan kurangnya kesadaran aparatur untuk bersikap etis dalam melaksanakan tugasnya sebagai pelayan masyarakat seperti bersikap ramah, sopan, dan santun. Kepala Dinas Kependudukan dan Pencatatan 
Sipil Kabupaten Mempawah mengungkapkan bahwa salah satu upaya yang dilakukan untuk meningkatkan kesadaran aparatur terhadap etika pelayanan adalah pada saat pelaksanaan rapat staf. Dengan demikian, telah ada upaya yang dilakukan oleh Dinas Kependudukan dan Pencatatan Sipil Kabupaten Mempawah dalam meningkatkan kesadaran aparatur terkait sikap perilaku dalam bekerja memberikan pelayanan kepada masyarakat.

Upaya tersebut dapat dikatakan sebagai salah satu bentuk tindakan yang dilakukan dalam menanggapi beberapa keluhan dari masyarakat mengenai perilaku aparatur. Meskipun terdapat aparatur yang bersikap kurang ramah, namun berdasarkan pengamatan peneliti Di Dinas Kependudukan dan Pencatatan Sipil Kabupaten Mempawah dapat dikatakan bahwa tidak semua aparatur bersikap kurang ramah dalam melaksanakan pelayanan kepada masayarakat. Pada saat peneliti meminta data untuk penelitian ini, mereka sangat ramah. Kepala Dinas Kependudukan dan Pencatatan Sipil Kabupaten Mempawah pun bersedia untuk saya wawancarai dan juga mengintruksikan kepada stafnya untuk memabantu saya mencarikan data yang peneliti butuhkan.

\section{Keadilan}

Keadilan adalah kondisi kebenaran moral yang ideal tentang sesuatu, baik itu benda maupun orang. Keadilan pada dasarnya keinginan untuk memberikan apa yang menjadi hak orang lain tanpa ada perbedaan di dalam pelaksanaannya, Adler (dalam Kumorotomo, 2018, 40). Aparatur harus bersikap netral dalam melayani setiap masyarakat yang datang ke kantor tanpa membedakan kelas social, gender, suku, ras maupun agama di dalam memberikan pelayanan. Dalam hal kaitannya dengan administrasi kependudukan khususnya pembuatan KTP elektronik. Dalam hal keadilan dalam pelayanan pembuatan KTP Elektronik memang setiap masyarakatnya memiliki persepsi yang berbeda-beda. Beberapa masyarakat berkata adil dalam hal pelayanan yang berkaitan dengan nomor antrian, menurut mereka aparatur melayani sesuai nomor antrian yang diberikan, tetapi yang tidak mendapatkan nomor antrian mengatakan kurang adil. Dalam melaksanakan pekerjaan tentunya ada pengawasan yang dilakukan oleh atasan kepada aparatur yang berada dibawahnya yang memberikan pelayanan langsung kepada masyarakat.

Dinas Kependudukan dan Pencatatan Sipil Kabupaten Mempawah bahwa ada pengawasan yang dilakukan oleh Kepala Dinas dan Kabid Pendaftaran Penduduk Dinas Kependudukan dan Pencatatan Sipil Kabupaten Mempawah selaku atasan yang bertanggung jawab pada bidang Dafduk terutama pada pekerjaan yang dilaksanakan oleh staf yang berada dibawahnya, bidang Dafduk sendiri merupakan bagian yang bertanggung jawab atas penerbitan kartu keluarga dan kartu tanda penduduk elektronik pada administrasi kependudukan di Disdukcapil Kabupaten Mempawah. Kemudian dari hasil pengamatan peneliti juga menemukan adanya aparatur yang memberikan pelayanan yang berbeda kepada salah satu masyarakat yang yang tidak memiliki nomor antrian, tetapi bisa masuk kedalam. Setelah peneliti telusuri ternyata orang tersebut merupakan salah satu keluarga oknum pegawai disana.

Dinas Kependudukan dan Pencatatan Sipil Kabupaten Mempawah harusnya berlaku adil di dalam pemenuhan suatu hak masyarakat dalam pelayanan yang berupa hasil pekerjaan dari tugas yang dilaksanakan oleh aparatur sesuai dengan apa yang telah dijanjikan sebagai bentuk tanggung jawab dalam bekerja. Dalam hal kaitannya dengan pelayanan administrasi kependudukan pembuatan KTP elektronik, tepat janji berarti aparatur harus memberikan hasil pekerjaannya kepada masyarakat sesuai dengan waktu yang telah ditentukan sebelumnya. Hal ini tentu sedikit banyak akan berdampak pada kepercayaan masyarakat terhadap aparatur pemerintah dalam bekerja, apabila yang 
dibutuhkan terpenuhi maka menimbulkan kepuasan bagi masyarakat, tetapi apabila sebaliknya justru akan mengakibatkan ketidakpuasan terhadap pelayanan yang diberikan. Terkait dengan tepat janji memang masih belum baik karena aparaturnya belum mampu menyelesaikan pekerjaannya dengan cepat dan tepat waktu sesuai dengan apa yang disampaikan kepada masyarakat terkait pembuatan KTP Elektronik, sehingga ada beberapa masyarakat yang mengeluhkan hal tersebut.

Selain itu, ada ketidaksesuaian antara waktu yang sudah ditentukan pihak Dinas Kependudukan dan Pencatatan Sipil Kabupaten Mempawah untuk pengambilan KTP Elektronik. Proses pembuatannya melebihi batas waktu yang sudah di informasikan oleh pihak Dinas Kependudukan dan Pencatatan Sipil Kabupaten Mempawah. Hal ini dikarenakan aparatur tidak bisa memberikan kepastian waktu penyelesaian kepada masyarakat dalam pelayanan. Dengan demikian dapat di lihat aparatur kurang mampu memberikan kepastian waktu dalam menyelesaikan tugas-tugasnya terkait dengan pembuatan KTP Elektonik. Hal ini disebakan oleh ketidaksesuaian antara waktu yang di informasikan ke masyarakat pada saat proses pelayanan pembuatan KTP Elektronik. Hal berdampak pada kurangnya kepuasan masyarakat terhadap pelayanan yang diberikan oleh Dinas Kependudukan dan Pencatatan Sipil Kabupaten Mempawah. Ketidakpastian waktu dalam pelayanan berkaitan dengan nilai efisiensi aparatur dalam melaksanakan tugas-tugasnya, pada nilai efisiensi sesuatu dapat dikatakan baik (etis) jika birokrat publik menjalankan tugas dan kewenangannya secara efisien.

Ketidakmampuan aparatur untuk menepati janji kepada masyarakat dalam memberikan kepastian waktu pelayanan disebabkan oleh keterbatasan jumlah aparatur yang bekerja pada Dinas Kependudukan dan Pencatatan Sipil Kabupaten Mempawah. Keterbatasan aparatur dalam bekerja merupakan salah satu kendala bagi Dinas Kependudukan dan Pencatatan Sipil Kabupaten Mempawah untuk melayani masyarakat secara cepat. Dengan keadaan aparatur yang minim tentu untuk melaksanakan pekerjaan agar dapat mencapai target harus ada cara yang dilakukan untuk mengatasi kendalakendala yang ada. Upaya yang dilakukan untuk mengatasi kendala pada Dinas Kependudukan dan Pencatatan Sipil Kabupaten Mempawah dalam melaksanakan tugastugasnya yaitu dengan melakukan lembur. Meskipun pada kenyataannya berdasarkan hasil pengamatan peneliti tidak semua aparatur melakukan pekerjaan lembur karena ada beberapa aparatur yang pulang kerja lebih awal dari waktu yang sudah ditentukan dalam peraturan kantor.

Selain lembur adalah dengan membawa pulang pekerjaan yang bisa dikerjakan dirumah. Dengan jumlah aparatur yang minim tentu sangat berpengaruh terhadap hasil dan kecepatan dalam bekerja, selain kewalahan karena harus mengerjakan banyak tugas yang harus ditangani, hasil yang diperoleh juga tidak sesuai dengan target waktu yang ditentukan. Meskipun demikian Dinas Kependudukan dan Pencatatan Sipil Kabupaten Mempawah telah berusaha memberikan pelayanan yang cukup maksimal meski kurang memuaskan masyarakat yang dikarenakan jumlah aparatur yang tersedia masih terbatas atau kurang.

\section{Taat Aturan}

Taat memiliki arti tidak berlaku curang, aturan adalah tindakan atau perbuatan yang harus dijalankan. Taat pada aturan adalah sikap atau tindakan yang mematuhi aturan yang telah dibuat. Ketaatan pada dasarnya kesanggupan pegawai untuk mengikuti dan melaksanakan setiap peraturan yang ada dan tidak melakukan perbuatan yang menyalahi aturan yang berlaku atau menyimpang dari pada suatu peraturan yang telah ditetapkan (Kumorotomo, 2018, 406). Aparatur tidak bisa berbuat semaunya atau sewenang-wenang tanpa mengikuti peraturan yang ada. Sebab sudah menjadi tanggung 
jawabnya menaati setiap peraturan yang berlaku dalam perundang-undangan maupun kedinasan. Namun pada kantor Disdukcapil Kabupaten Mempawah berdasarkan hasil pengamatan peneliti ada beberapa pegawai yang kurang taat terhadap aturan, salah satunya aturan mengenai kedisiplinan dalam bekerja.

Hasil penelitian lapangan, terlihat kondisi ruangan Ruang Staf Bidang Pendaftaran Penduduk Dinas Kependudukan dan Pencatatan Sipil Kabupaten Mempawah masih kosong pada saat jam sudah menunjukan pukul 09:24 WIB, padahal jam kerja kantor dimulai pukul 09:00 WIB. Dari hasil pengamatan peneliti Di Dinas Kependudukan dan Pencatatan Sipil Kabupaten Mempawah ada aparatur yang datang bekerja tidak tepat waktu, hal ini mengidentifikasikan bahwa aparatur kurang disiplin dalam bekerja pada saat jam kerja. Hasil wawancara, pengamatan dan Dokumentasi yang telah di paparkan diatas dapat dilihat terjadi kekosongan dalam ruang kerja aparatur, pada gambar tersebut tidak ada aparatur yang berada di dalam ruangan pada saat jam pelayanan yang seharusnya telah dimulai. Dengan demikian dapat dikatakan Aparatur Di Dinas Kependudukan dan Pencatatan Sipil Kabupaten Mempawah tidak disiplin pada waktu datang bekerja.

Aparatur Dinas Kependudukan dan Pencatatan Sipil Kabupaten Mempawah menyampaikan akan ada sanksi yang diterima atas ketidakdisiplinan di dalam bekerja. Kenyataanya dari hasil pengamatan langsung peneliti dilapangan, masih ditemukan staf pegawai yang datang tidak sesuai dengan jam operasional pelayanan. Hal ini tentu tidak dapat dibenarkan karena dapat mengganggu proses percepatan dalam pelayanan yang akan menyebabkan lambatnya pelaksanaan pelayanan kepada masyarakat. Disiplin sendiri merupakan salah satu norma etik di dalam pemerintahan yang harus diaplikasikan oleh aparatur dalam tugasnya yaitu pelayanan. Apabila tidak diterapkan dengan baik maka telah melanggar salah satu bentuk nilai-nilai dasar kode etik Pegawai ASN (Aparatur Sipil Negara) dalam bersikap/berperilaku etis.

\section{Tanggung Jawab}

Tanggung jawab adalah suatu pengertian dasar untuk memahami manusia sebagai makhluk susila dan tinggi rendahnya akhlak yang dimilikinya. Terkait rasa tanggung jawab, manusia melandasi anggapannya dengan mengakui kenyataan bahwa manusia dalam hubungan yang sempit dan luas memerlukan satu sama lain untuk mewujudkan nilai-nilai kehidupan yang dirasanya baik dan menunjang eksistensi dirinya. Tanggung jawab kemudian berkembang bukan hanya pada tataran personal, tetapi selalu dikaitkan dengan hubungan dengan orang lain. Tanggung jawab merupakan kesanggupan pegawai untuk mengerjakan dan melaksanakan tugas-tugas dengan baik dan sesuai waktu yang ditargetkan serta menerima segala akibat atau beban dari keputusan yang dibuatnya (Kumorotomo, 2018, 406). Aparatur harus memiliki ketekunan dalam bekerja melaksanakan tugas-tugasnya untuk memenuhi kebutuhan masyarakat dengan mampu berkomitmen untuk bisa memberikan kepastian waktu dalam pelayanan kepada masyarakat. Dinas Kependudukan dan Pencatatan Sipil Kabupaten Mempawah menerapkan atau melaksanakan pekerjaan dengan tetap berpegang pada peraturan yang berlaku, karena peraturan merupakan dasar hukum bagi setiap instansi manapun dalam melakukan pekerjaan yang diembankan kepada para birokrat selaku ASN sebagai bentuk tugasnya dalam melayani masyarakat.

Dinas Kependudukan dan Pencatatan Sipil Kabupaten Mempawah melakukan kerjasama antara bidang yang 1 (satu) dengan bidang lainnya untuk sama-sama menyelesaikan pekerjaan yang merupakan tanggung jawab Dinas Kependudukan dan Pencatatan Sipil Kabupaten Mempawah. Kerjasama antar berbagai bidang yang ada di dalamnya ini dari hasil pengamatan peneliti Di Dinas Kependudukan dan Pencatatan Sipil 
Kabupaten Mempawah aparaturnya bekerja secara merangkap ke berbagai bidang dan tidak terpaku pada satu bidang saja, misalnya pada bidang Dafduk aparatur tersebut juga diminta untuk membantu pada bidang Sipil atau pun bidang SIAK (Sistem Informasi Administrasi Kependuddukan) atau sebaliknya dari bidang lain merangkap ke bidang Dafduk, hal ini dikarenakan Dinas Kependudukan dan Pencatatan Sipil Kabupaten Mempawah memiliki keterbatasan jumlah aparatur SDM (Sumber Daya Manusia).

Dari Sudut pandang masyarakat dapat dikatakan aparatur masih belum sepenuhnya mampu menyelesaikan tugas sesuai target yang ditentukan, sehingga pelayanan menjadi sedikit lambat dan menyebabkan timbulnya kesan kurang bertanggung jawab dalam bekerja. Aparatur Di Dinas Kependudukan dan Pencatatan Sipil Kabupaten Mempawah kurang memenuhi tanggung jawabnya sebagai pelaksana dan pemberi pelayanan kepada masyarakat karena belum mampu memberikan kepastian waktu dalam pelayanan dan informasi yang jelas kepada masyarakat. Masyarakat tentu perlu mengetahui atau memperoleh informasi secara jelas, apakah hasil dari tugas yang dikerjakan sudah selesai atau belum dan sedang dalam proses. Dengan memperoleh informasi yang jelas tentu masyarakat merasa puas dan tidak membuang banyak waktu hanya untuk mengurus hal yang sama secara berkali-kali.

Dari hasil penelitian memang terdapat beberapa aparatur yang mudah sedikit emosional pada saat masyarakat bertanya. Hal ini dapat dilihat dari mimik wajah atau intonasi suara saat menjawab masyarakat. Sebagai seorang birokrat yang bertugas melayani masyarakat, aparatur sudah seharusnya memenuhi tanggung jawabnya dalam bekerja dengan bersikap cepat tanggap dan tidak mudah marah (emosional) pada saat masyarakat bertanya. Tanggung jawab yang baik tidak hanya di lihat bagaimana pekerjaan dapat terselesaikan sesuai target waktu yang di tentukan saja, tetapi juga bisa dilihat bagaimana sikap/perilaku yang di tunjukan pada saat melayani masyarakat. Melayani dengan sopan dan santun juga merupakan bagian dari tugas ASN sebagai pelayan masyarakat, dimana hal tersebut sudah tertera dengan jelas dalam UndangUndang Nomor 5 tahun 2014 tentang ASN (Aparatur Sipil Negara). Hal ini tentu berkaitan dengan sikap perilaku etis aparatur dalam menjaga nilai-nilai dasar kode etik Pegawai ASN (Aparatur Sipil Negara).

\section{Kewajaran dan Kepatutan}

Kewajaran merupakan persamaan dalam memberikan hak kepada stakeholder sesuai dengan peraturan yang ditetapkan (Pasolong, 2017, 260). Dalam melaksanakan tugasnya sebagai pelayan masyarakat, aparatur sudah seharusnya menunjukan sikap wajar maupun patut pada saat memberikan pelayanan. Dengan menerapkan sikap wajar dan patut tentu akan mendapatkan respon yang positif dan memberikan rasa puas bagi masyarakat setelah memperoleh pelayanan. Namun Di Dinas Kependudukan dan Pencatatan Sipil Kabupaten Mempawah, terkait dengan kewajaran dan kepatutan sikap aparatur masih dikatakan kurang baik karena ada beberapa aparatur yang kurang menunjukan keramahan dalam melayani masyarakat. Padahal masyarakat berhak memperoleh perlakuan sikap yang baik melalui pelayanan yang di dapatkan. Dapat dilihat bahwa saat melaksanakan tugasnya aparatur Dinas Kependudukan dan Pencatatan Sipil Kabupaten Mempawah belum bisa menunjukan kewajaran atau kepatutannya dalam bersikap perilaku yang baik dalam melayani masyarakat, khususnya dalam pembuatan KTP Elekronik. Dimana aparatur melayani dengan sikap yang cuek dan mimik wajah yang di sedap dipandang, sehingga pelayanan menjadi kurang nyaman. Kewajaran yang dimaksud adalah keramahan dalam pelayanan, masyarakat tentu berhak memperoleh pelayanan yang baik dan juga kepuasan melalui jasa yang diperolehnya baik itu jasa bersifat fisik maupun yang nonfisik. 
Terkait dengan Kewajaran dan kepatutan dalam bersikap/perilaku, aparatur Di Dinas Kependudukan dan Pencatatan Sipil Kabupaten Mempawah masih belum baik. Hal ini di sebabkan kurangnya kerahamahan aparatur dalam melayani masyarakat. Peneliti melihat, penyebab dari kurang ramah tersebut dapat dilihat dari mimik wajah, intonasi suara, dan cara mereka melayani yang berbeda-beda. Dalam memberikan pelayanan tentu penting bagi aparatur untuk memperhatikan sikapnya saat melayani masyarakat. Kurangnya kesadaran pada diri aparatur untuk menerapkan sikap etis dalam menjaga nilai-nilai dasar yang terdapat pada kode etik ASN (Aparatur Sipil Negara) yang seharusnya menjadi pedoman bagi aparatur dalam bersikap/perilaku saat melaksanakan tugas-tugasnya, menyebabkan penerapan etika dalam pelayanan oleh aparatur terlihat minim pada praktek pelayanannya. Pelayanan dengan sikap yang ramah dan sopan akan memberikan kepuasan dan menimbulkan tingkat kepercayaan yang baik kepada aparatur pemerintah dari masyarakat.

\section{KESIMPULAN}

Hasil penelitian mengenai Etika Aparatur Sipil Negara Dalam Pelayanan pembuatan KTP Elektronik Di Dinas Kependudukan dan Pencatatan Sipil Kabupaten Mempawah yang dilihat dari kejujuran, keadilan, tepat janji, taat aturan, tanggungjawab, kewajaran dan kepatutan dalam pelayanan dapat disimpulkan sebagai berikut:

1. Kejujuran Aparatur Sipil Negara Dalam Pelayanan Pembuatan KTP Elektronik di Kantor Dinas Kependudukan dan Pencatatan Sipil Kabupaten Mempawah Pada Masa Covid 19 dalam bekerja sudah baik, hal ini dapat dilihat dari tidak adanya penyalahgunaan wewenang di dalam pelaksanaan tugas seperti melakukan pungutan liar dan tidak menutup-nutupi adanya keluhan yang didapatkan dari masyarakat terkait sikap yang kurang memuaskan dalam memberikan pelayanan.

2. Keadilan Aparatur Sipil Negara Dalam Pelayanan Pembuatan KTP Elektronik di Kantor Dinas Kependudukan dan Pencatatan Sipil Kabupaten Mempawah Pada Masa Covid 19 belum baik karena informasi tentang kartu tanda penduduk yang diberikan kurang jelas dan adanya perbedaan dalam memberikan pelayanan kepada masyarakat. Selain itu aparatur belum mampu menyelesaikan tugas dengan tepat waktu sesuai dengan yang sudah dijanjikan.

3. Taat Aturan Aparatur Sipil Negara Dalam Pelayanan Pembuatan KTP Elektronik di Kantor Dinas Kependudukan dan Pencatatan Sipil Kabupaten Mempawah Pada Masa Covid 19 masih belum baik, hal ini dapat dilihat dari adanya aparatur yang kurang menaati peraturan yaitu terkait disiplin jam kerja.

4. Tanggung jawab Aparatur Sipil Negara Dalam Pelayanan Pembuatan KTP Elektronik di Kantor Dinas Kependudukan dan Pencatatan Sipil Kabupaten Mempawah Pada Masa Covid 19 belum baik di karenakan belum mampu memberikan kepastian waktu dalam pelayanan dan informasi yang jelas kepada masyarakat.

5. Kewajaran dan Kepatutan Aparatur Sipil Negara Dalam Pelayanan Pembuatan KTP Elektronik di Kantor Dinas Kependudukan dan Pencatatan Sipil Kabupaten Mempawah Pada Masa Covid 19 masih belum baik, hal ini dapat dilihat dari kurangnya kerahamahan aparatur dalam melayani masyarakat yang bertanya terkait dengan pembuatan KTP Elektronik.

\section{DAFTAR PUSTAKA}

Bayley, D. H. (2001). Democratizing the police abroad: What to do and how to do it (Vol. 3). US Department of Justice, Office of Justice Programs, National Institute of Justice. Indradi, S. S. (2010). Etika Birokrasi dan Akuntabilitas Sektor Publik. Malang: YPN, CV Sofa Mandiri dan Indonesia Print. 
Inu, S. K. (2011). Etika Pemerintahan: Dari Keseimbangan Good Governance Dengan Clean Government Sampai Pada State of The Art Ilmu Pemerintahan Dalam Mengubah Pemerintah Biadan Menjadi Pemerintah Beradab.

Martini, R. (2010). Politisasi birokrasi di Indonesia. POLITIKA Jurnal Ilmu Politik $M I P, 1(1), 67-74$.

Wahyudi, K. (1992). Etika Administrasi Negara. Jakarta: PT Raja Grafindo Persada.

Nurdin, M. S. (2017). Etika Pemerintahan: Norma, Konsep, dan Praktek bagi Penyelenggara Pemerintahan. Lintang Rasi Aksara Books.

Harbani, P. (2007). Teori Administrasi Publik. Bandung: Alfabeta.

Peraturan Menteri Dalam Negeri Republik Indonesia Nomor 19 Tahun 2018 Tentang Peningkatan Kualitas layanan Administrasi Kependudukan.

Rohman, A. A., \& Arif, S. (2008). Reformasi pelayanan publik. Averroes Press.

Santosa, P. (2008). Administrasi Publik Teori dan Aplikasi Good Governance.

Djam'an Satori, A. K. (2011). Metode Penelitian Kualitatif. Bandung. Alfabeta.

Sinambela, L. Poltak, dkk, 2011. Reformasi Pelayanan Publik, Teori, Kebijakan dan Implementasi, Bumi Aksara, Jakarta.

Sufianto, D. (2016). Etika pemerintahan di Indonesia. Alfabeta.

Sumaryadi, I. N., Indraatmaja, A. B., \& Hutabarat, N. E. (2010). Sosiologi pemerintahan: dari perspektif pelayanan, pemberdayaan, interaksi, dan sistem kepemimpinan pemerintahan Indonesia. Ghalia Indonesia.

Surjadi. (2009). Pengembangan Kinerja Pelayanan Publik. Refika Aditama.

Duha, T. (2018). Perilaku organisasi. Deepublish.

Undang-Undang Nomor 25 Tahun 2009 Tentang Pelayanan Publik.

Undang-Undang Nomor 5 Tahun 2014 Tentang Aparatur Sipil Negara 